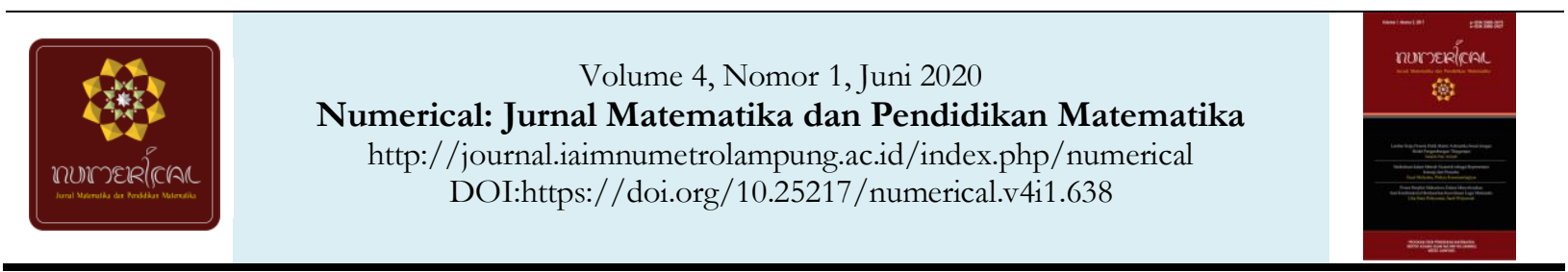

\title{
Comparison of Students' Covariational Reasoning Based on Differences in Field-Dependent and Field-Independent Cognitive Style
}

\author{
Ulumul Umah
}

Universitas Pesantren Tinggi Darul Ulum Jombang, Indonesia

Correspondence: $₫$ ulumul.ummah@gmail.com

\begin{tabular}{|c|c|}
\hline Article Info & Abstract \\
\hline $\begin{array}{l}\text { Article History } \\
\text { Received: 30-11-2019 } \\
\text { Revised: 10-06-2020 } \\
\text { Accepted: 12-06-2020 } \\
\text { Keywords: }\end{array}$ & $\begin{array}{l}\text { Students' difficulty in calculus can be related to their ability in covariational } \\
\text { reasoning in school or college. Reasoning process involves high-level cognition. } \\
\text { Nevertheless, the relationship between cognitive style and covariational reasoning } \\
\text { has not been investigated more specifically. Cognitive style in this study was } \\
\text { characterized by field-dependent and field-independent category. This paper } \\
\text { describes the covariational reasoning process of field-dependent and field- } \\
\text { independent students while constructing the graph of dynamic events. Students' } \\
\text { cognitive style data obtained through the Group Embedded Figures Test (GEFT), } \\
\text { while the covariational reasoning data obtained through the covariational problem } \\
\text { test and verified by several interviews. The results showed that there was no } \\
\text { significant consistent difference between field-dependent and field-independent } \\
\text { students in their covariational reasoning level, but there were differences in } \\
\text { students' way of reacting to the context of the problems. Field-dependent subjects } \\
\text { exhibited their mental action inconsistently when they faced a new problem that } \\
\text { more complex than before. This finding indicated that we need to set the problem } \\
\text { to make it an effective stimulus in developing student's covariational reasoning } \\
\text { ability. }\end{array}$ \\
\hline
\end{tabular}

\section{INTRODUCTION}

More than two decades, Researchers has shown the students' difficulty understanding the concepts of calculus caused by the weakness of their understanding of the concept of a function [1][2]. Covariational reasoning is a fundamental ability that students must have to be ready to learn calculus [3][4][5][6] because this reasoning plays a role in shaping students' views of function. The way of thinking when students construct, interpret, and use functions are meaningfully formed when students reason about variation [3].

Covariational reasoning was first explicitly defined by Carlson, Jacobs, Coe, Larsen, \& Hsu [7] as cognitive activities in coordinating two related quantities simultaneously. This reasoning process is characterized by mental actions that explain a person's level of covariational reasoning, namely level 1 (coordination), level 2 (direction), level 3 (quantitative coordination), level 4 (average rate), and level 5 (instantaneous rate). The subject's ability to determine the exact direction of the curve's curvature when asked to construct a graph based on a dynamic event situation can be an early indication of achieving the highest level (level 5), although there is still a possibility that the graph is not produced by correct reasoning [8] so more investigation is needed continued. These five levels of reasoning are then refined by Thompson \& Carlson [9] by paying attention to the work of Castillo-Garsow [10][11] on how individuals understand how quantities vary so that new 6 levels of formulation of covariational reasoning form. The revised level 
consists of levels of "no coordination", "pre-coordination of values", "gross coordination of values", "coordination of values", "chunky continuous covariation", and "smooth continuous covariation". The task of covariation is to identify the level of covariational reasoning in the form of instructions for constructing graphs that represent dynamic situations in the real world. The task of covariation encourages students to understand the relationship between quantities contained in verbal information from real problems and builds meaningful graphs and formulas to represent these relationships [3].

Reasoning involves mental actions which are high-level cognitive processes. Based on Piaget's theory, a person's cognitive development occurs through a process of assimilation and accommodation, where both of these processes occur with complementary [12][13]. Assimilation is the process of obtaining information based on the knowledge that has been held previously in the form of the old scheme, while the accommodation is an adjustment process that has owned the scheme after receiving new information. Covariational reasoning can be seen as a thought process that involves the process of assimilation and accommodation, and imperfections in both processes can lead to pseudo reasoning thinking [8].

Herbert Witkin formulates individual characteristics can be distinguished based on cognitive style [14]. This cognitive style does not refer to the content of information, but rather about how the brain receives and processes information. Witkin's theory distinguishes the characteristics of cognitive styles as field-dependent and field-independent based on one's way of thinking and perception of pieces of information that are affected by the context that surrounds them. Field-dependent individuals are more easily influenced by surrounding contexts, whereas field-independent individuals are not easily affected because it can isolate target information even though it is surrounded by a broader and more complicated context [15]. Therefore, fielddependent individuals are superior insensitivity in the social environment, while field-independent individuals are more analytical and interested in abstract and theoretical matters. Nevertheless, it should be remembered that these different characteristics do not necessarily divide individual groups into two parts as categorizing black-and-white, but rather look at the relative tendencies as to judge someone tall or short [16][15].

Further studies of covariational reasoning have not been sufficient to explain explicitly about the factors of cognitive style differences that affect one's performance in covariational reasoning [5][17][18][19][20]. However, the relationship between cognitive style and reasoning ability, in general, can be traced to the relationship based on a study of working memory capacity. Working memory is defined as a work desk for changing, combining, and updating old and new information constantly [13]. Efficiency in filtering out information which is irrelevant or which is no longer relevant becomes a potential individual difference in complex cognition, including reasoning [21]. Reasoning requires the construction of new representational structures, while the complexity of these new structures is limited by the capacity of working memory [21]. This limitation factor of working memory capacity does not mean that reasoning is the ability to remember pieces of information, but rather the ability to put them together into a scheme [22].

Identification of covariational reasoning as well as field-dependent/field-independent cognitive styles involves visual ability when constructing graphs on covariate assignments and finding images that fit the cognitive style test. A visualization is an important tool in solving mathematical problems and it relates to reducing the demands on working memory [23]. Therefore, it is quite possible that individuals with different cognitive styles also show the reasoning covariational at different levels. 
Understanding of calculus is still a particular difficulty for students [24][25][26][27] and covariational reasoning when constructing graphs of the functions of dynamic events is one indicator of student readiness in learning calculus [4]. Research shows that students often still experience difficulties in covariational reasoning [28][29]. To improve students' reasoning abilities, sufficient information is needed to design effective learning, including how they should be in designing covariation tasks. The difference in how to process information in individuals with a field-dependent / field-independent cognitive style is thought to have a role in the process of covariational reasoning so that the same stimulus will be processed differently and the results may also be different. However, there is not enough strong evidence regarding differences in covariational reasoning abilities based on differences in cognitive styles. Thus, further research is needed to find out in-depth the reasoning process of each subject with different cognitive styles. This study aims to describe the comparison of covariational reasoning between field-dependent subjects and field-independent subjects when constructing function graphs based on problems of dynamic event situations.

\section{METHOD}

This study uses a qualitative approach with case studies to compare the process of covariational reasoning on four subjects consisting of two field-dependent and two fieldindependent. The study was conducted in the study program Mathematics and Mathematics Education High Pesantren Darul Ulum University Jombang. Retrieval of data takes place in JuneAugust 2018. Each study subject was given the task covariational and followed by an interview session for three sessions. The results of the written responses and interview transcripts were analyzed qualitatively based reasoning framework covariational level. A description of the subject of research, data collection instruments, and data analysis are described as follows.

\section{Research Subject}

A total of 12 Mathematics and Mathematics Education students took the Witkinn Group Embedded Figures Test (GEFT) cognitive style test to identify field-dependent or fieldindependent trends. Student participants were categorized based on the provisions of a score of 0-8 (field-dependent), a score of 9-14 (field-neutral), and a score of 15-18 (field-independent) [30]. The cognitive style test results for all participants are presented in Table 1. Based on the results of the test, four subjects were selected for their covariational reasoning, namely DH, EN, SW, AK. This subject selection is based on the consideration of not including subjects in the field-neutral category. To control the sex factor, two male subjects and two female subjects were chosen with each sex group consisting of one field-dependent subject and one field-independent subject. The difference in scores between the two field-dependent subjects is controlled so as minimal as possible, as well as for field-independent subjects. Besides, the four selected subjects have similar performance in daily learning activities and are in the average category. 
Table 1. Participant GEFT Results

\begin{tabular}{lcccc}
\hline No & Participants & Gender & Scor & Cognitive Style Categories \\
\hline 1 & LK & Female & 11 & Field-neutral \\
2 & RF & Female & 3 & Field-dependent \\
3 & DH & Female & 17 & Field-independent \\
4 & EN & Female & 8 & Field-dependent \\
5 & RR & Female & 13 & Field-neutral \\
6 & SR & Female & 16 & Field-independent \\
7 & DA & Male & 13 & Field-neutral \\
8 & SW & Male & 6 & Field-dependent \\
9 & PR & Female & 8 & Field-dependent \\
10 & AZ & Female & 14 & Field-neutral \\
11 & AK & Male & 16 & Field-independent \\
12 & LR & Female & 8 & Field-dependent \\
\hline
\end{tabular}

\section{Data Collection Instruments}

In this study, researchers act as the main instrument to collect, analyze, and interpret data with auxiliary instruments GEFT and covariation task. After obtaining data regarding cognitive styles with GEFT, researchers collected data for subjects completing the task covariational then conducted interviews to understand more about the process of thinking subject. During the interview, the researchers avoid the intervention of the response of the subject, but researchers can develop a question from the covariation task if necessary. The collection, interpretation, and analysis of the data conducted by researchers simultaneously and repeatedly throughout the study.

\section{Cognitive Style Test}

Cognitive styles subjects identified by the Group Embedded Figures Test (GEFT). This test sheet contains a set of simple geometric figures and the subjects were asked to determine its location on the image that is composed of intersecting lines wider and complex (sample item in GEFT can be seen in Figure 1). Subject field-dependent takes longer and have fewer pictures than people with independent field style.

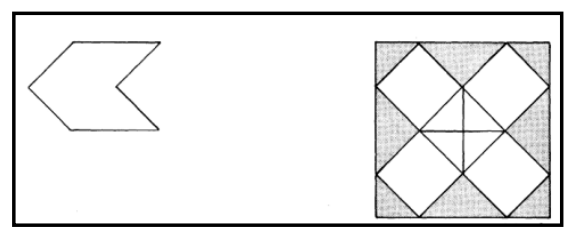

Figure 1. Build simple geometry (left) and build complex geometry (right) in GEFT

\section{Covariation Task}

The covariation tasks include problems compiled by researchers and some of the problems were adapted from several previous studies [7][31][8][32]. The type of problem and content of covariation tasks presented in Table 2. The covariation task designed with two different issues, namely the context of changes in position and changes in water volume to 
determine the level of consistency of reasoning subject. The covariation task also includes the task of graph interpretation to check the reasoning not only through the construction of the graph but also from the opposite direction.

Table 2. Types of Problems and Content of Covariation Task

\begin{tabular}{lll}
\hline \multicolumn{1}{c}{ Types of } \\
Problems
\end{tabular}

\section{Data Analysis}

Each of the four research subjects was asked to work on a variety of assignments in three sessions on different days. In the first session, the subjects performed tasks 1 and 2 with the context of the problem of position change, the second session of tasks 3,4 and 5 with the context of the problem of changes in water volume, the third session of tasks 6 and 7 covered the context of the problem of changing the volume of water with a low level of complexity and 
graphical interpretation. In each session, subjects were interviewed after working on a variation task. The process of collecting, analyzing, and interpreting data is carried out simultaneously. Information from the subject's written answers and transcript of the interview recording is reduced and coded so that it can be grouped by theme. Furthermore, the data are categorized based on the level of covariational reasoning descriptors in Table 3. To ensure the validity of the data, the researcher compares the data obtained from each of the three sessions to ensure consistency. In-depth interviews were also conducted to clarify the findings obtained from the subject's written answers.

Table 3. Major Levels of Reasoning Covariation [9]

\begin{tabular}{ll}
\hline \multicolumn{1}{c}{ Levels } & \multicolumn{1}{c}{ Descriptions } \\
\hline $\begin{array}{l}\text { Smooth Continuous } \\
\text { Covariation }\end{array}$ & $\begin{array}{l}\text { Someone imagines an increase or decrease (change) in one quantity or value } \\
\text { of a variable occurring simultaneously with changes in the value of another } \\
\text { variable, and he imagines the two variables vary continuously and smoothly. } \\
\text { Chunky Continuous } \\
\text { Covariation }\end{array}$ \\
$\begin{array}{l}\text { Someone imagines that changes in the value of one variable occur } \\
\text { simultaneously with changes in the value of another variable, and he } \\
\text { imagines both variables vary with continuous variations but in the form of } \\
\text { pieces (chunky) }\end{array}$ \\
$\begin{array}{l}\text { Someone coordinates the value of one variable }(x) \text { with the values of another } \\
\text { Value }\end{array}$ \\
$\begin{array}{l}\text { Gross Coordination }(y) \text { by anticipating creating a collection of discrete pairs }(x, y) . \\
\text { of Values }\end{array}$ & $\begin{array}{l}\text { Someone forms a rough idea of the value of a quantity that varies together, } \\
\text { such as "this quantity increases while another quantity decreases". He does } \\
\text { not imagine that individual values in quantity go hand in hand }\end{array}$ \\
Pre-Coordination of & $\begin{array}{l}\text { Someone imagines two variable values to vary, but not synchronously } \\
\text { Values }\end{array}$ \\
No Coordination & $\begin{array}{l}\text { Someone does not have a picture of the variables that vary together. It } \\
\text { focuses on variations of one variable or other variables without coordinating } \\
\text { values. }\end{array}$ \\
\hline
\end{tabular}

\section{RESULTS AND DISCUSSION}

\section{Field-Dependent Subjects' Covariational Reasoning}

The two subjects with field-dependent style in this study did not always show the same level of reasoning. SW can reach the highest level of coordination of values while EN can reach the level of gross coordination of values in the context of a particular problem. However, both of these subjects experience a change in the level of reasoning in doing variation tasks when there is a change in the context of the problem. EN can coordinate grades appropriately on covariation task 1, but can only coordinate gross values on covariation tasks 3, 5, and 6 (Figure 2), even on covariation task $4 \mathrm{EN}$ only reaches pre-coordination scores because it cannot show the direction of change correctly (Figure 3). Likewise, the SW could not determine the exact direction of change in the Variation 4 task (Figure 4) even though he could do it correctly in the variation task. subject charts sometimes lose focus on the direction of the change due to the complexity of the situation presented or information covering the situation, such as changes in the water rate. Besides, the two subjects were also affected by the word "constant" in the covariate 3 task to produce a graph without slope changes. This is evident in the verbal statement EN in the following assignment 3 . 
EN : $x$ this is the amount of water and this height is $y$, for example, at a rate of 10 litres per minute, the graph will increase. So the amount of water is 10 litres, the height is 10 meters .......... it is constant, the increase is 10 , the water 20 litres is 20 ".

The SW in the following interview passage also shows the effect of the word "constant" on the covariate task 3 .

SW : Because the rate is always constant, the amount of water is equal to the height of the water. So suppose this amount of water is here so the height also equates to that much water

Q : Is there any influence from the shape of this bottle, when it is convex like this with a straight one?

\section{SW : Different}

$\mathrm{P} \quad$ : what's the difference?

SW : For convex ones, the amount of water will be greater. The convex height is smaller than the non-convex one

Q : does it affect the shape of the graph?

SW : No.

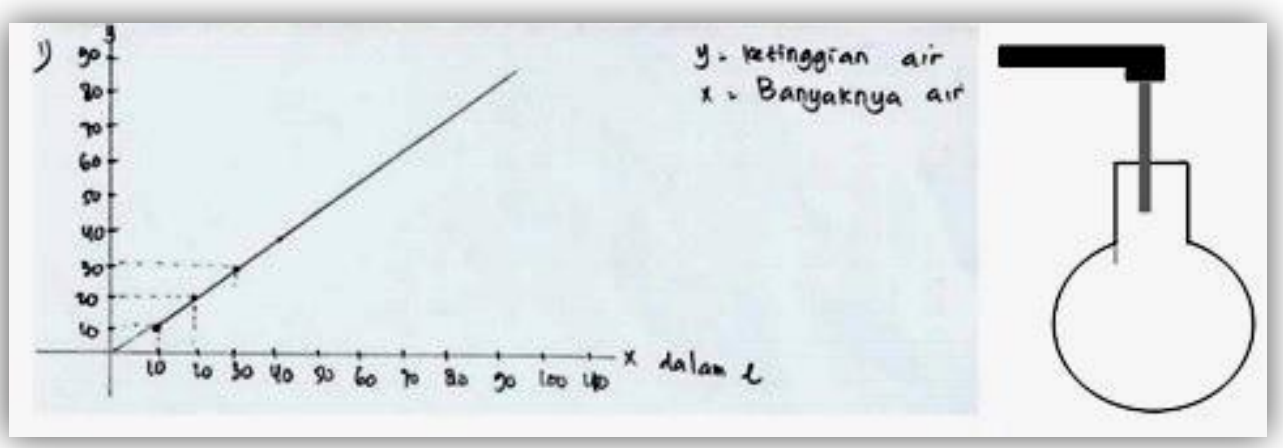

Figure 2. Graph by EN on the covariation task 2

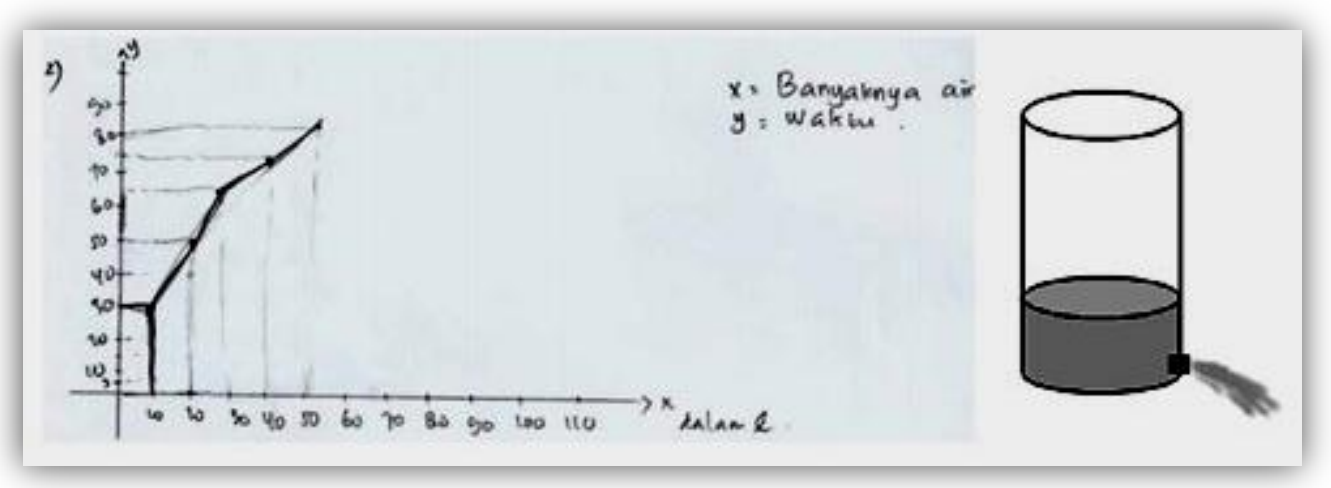

Figure 3. Graph by EN on the covariation task 3 


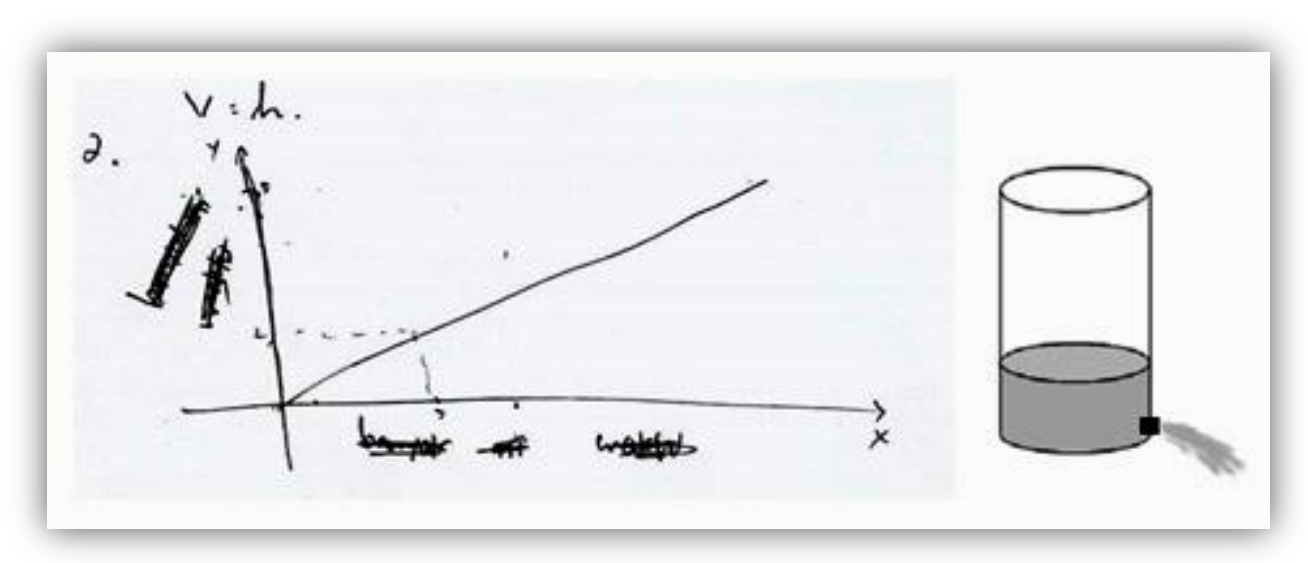

Figure 4. Graph by SW on the covariation task 3

Initial awareness of the continuous coordination can be shown by two subjects when getting the task of chart interpretation and this awareness is more common in SW revising graph of covariation task 6 after trying to interpret the graph on task 7.

Although SW was able to construct the smooth curve at one time after gaining experience in the interpretation, but he has not been able to construct the right direction of concavity consistently. He was not able to show an understanding of what situation cause the curve concave upwards and not downwards. The influence of the task of graph interpretation at raising awareness of the subject heading higher covariational reasoning, but they have not been able to apply it in another context.

\section{Field-Independet Subjects' Covariational Reasoning}

Field-independent subjects can show the reasoning for continuous covariation. AK showed chunky continuous coordination and expressed it in the graph (Figure 5). While DH indicated the awareness of smooth continuous covariation (Figure 6) although it was not successful consistently stated it in the graph (Figure 7). AK consistently showed an awareness of the coordination of the direction of change, both when the graph had to go up or down even though sometimes it had to go through reflections on his thinking. Coordination of change direction by $\mathrm{AK}$ is not much influenced by the complexity of the problem or the information surrounding the core information. AK realized that the slope of the different lines showed the rate of change in the dependent variable when there was a uniform change in the independent variable. AK can show that to change the tilt that is getting straighter or more horizontal based on differences in speed. For example, during the second session of the test and interview, AK can evaluate the graph which is initially in the form of line segments that are getting straighter and convert them into line segments whose slopes are getting more horizontal.

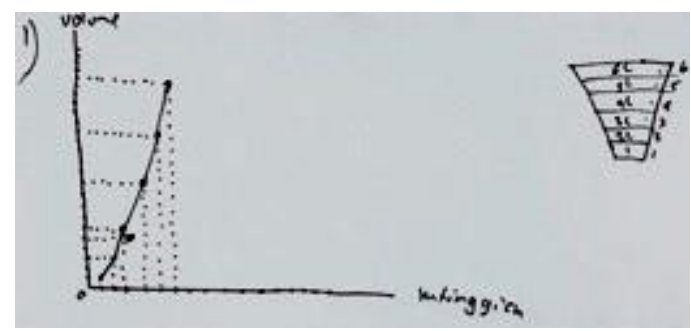

Figure 5. Graph by AK on the covariation task 6 


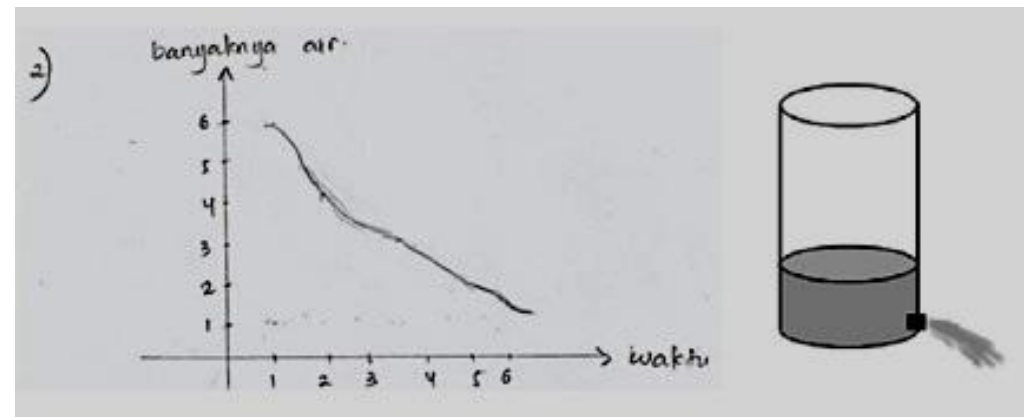

Figure 6. Graph by DH on the covariation task 3

AK uses the help of unconventional visual representations to assist the reasoning process (as in Figure 5), which then becomes the basis for constructing formal graphs. AK had experienced errors on the direction of coordination in the covariation task 1, but these errors result from differences in the perception of the variable "time" and not based on the level of reasoning. When AK gain experience interpreting graphs in the form of a smooth curve that is concave, AK started to realize how to represent the changes that occur continuously and "smooth". Nonetheless, AK has not implemented on the graph. The initial awareness can be a potential to increase the level of reasoning.

DH can show awareness that the value of the variable y changes according to the change in the variable $x$. DH consistently showed the correct direction of change in the tests and interviews in three sessions. Like $\mathrm{AK}, \mathrm{DH}$ also misrepresents task 1 but it does not result from wrong reasoning but because of different perceptions about the "time" variable. The subject seemed to have smooth continuous covariation awareness, but could not represent it correctly. This can be seen from the verbal statement by the $\mathrm{DH}$ regarding the coordination of changes continuously at certain intervals but has difficulty when applying them in the graph.

"The more the volume goes up, the height increases, because the shape of the glass is wider at the top, so the height is also not too big ...

but the lower one is faster because the shape of the bottom container is small so it fills up quickly"

$\mathrm{DH}$ did not begin the construction of a smooth curve graph by noting the slope changes in the line segments. Although at one time he could construct graphs with the appropriate concavity, he could not do it right for a different case. This can be seen when the subject is asked to change the position of the variable on a different axis, $\mathrm{DH}$ does not change the direction of concavity (Figure 7).

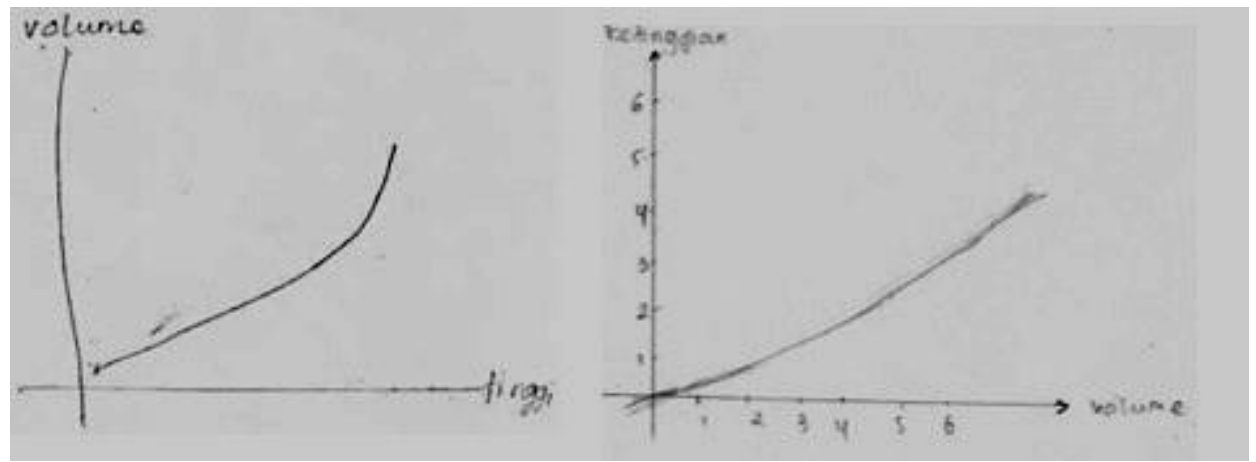

Figure 7. DH graph on the covariation task 6 


\section{Comparison of Covariational Reasoning Processes Based on Differences in Cognitive Style}

Similar to other studies of students' covariational reasoning abilities [28][33][34], these four research subjects also faced a "struggle" when facing assignments related to covariation. Determining the concavity of the graph is the difficulty experienced by all subjects. No subject shows the smooth continuous covariation level consistently every covariation task, although in certain subjects there is an initial awareness about it.

Based on comparisons in two cases of field-dependent subjects and two cases of independent field subjects on tests and interviews over three sessions, no consistent differences were found regarding the level of reasoning of individuals with different cognitive styles although there was a tendency for higher levels of reasoning in independent field subjects. Theoretically, in general, the positive effects of independent fields are more visible in science, while dependent fields are superior in social contexts [15]. However, the initiation of this cognitive style categorization notes that differences in cognitive styles do not indicate differences in abilities, but rather as differences in response to the environment and learning content [14].

The differences found consistently in subjects with different cognitive styles are the way they identify the information needed and how strongly they are affected by the context of the problems that surround them or the problems they have faced before. The different levels of reasoning that are found can be caused by the difficulty of field-independent subject in separating the information needed from other contexts that included in the covariation problem. When the situation in the problem is simpler, field-independent subjects was able to use reasoning better than when there is additional information or an increased level of complexity of the problem. The reasoning is high-level mathematical thinking and therefore requires cognitive ability to process information efficiently so that it can use the capacity of working memory to the optimum[21]. Mathematical thinking is a process in the part of the human brain and depends on how information is inputted, processed internally, outputted, and communicated [33]. Thus, it is necessary to pay attention to the cognitive aspects of how an individual thinks about mathematical structures.

The task of covariation involves the ability to read texts containing real-life problems and transform them into the mathematical language which can be a difficult task for some individuals. The reading process involves thinking modes which can be problematic [33]. Regarding the type of covariation problem presented, problems with time variables give rise to more varies subject perceptions about the "time" variable which is considered to be the same as speed or duration. Problems like this are less supportive for subjects who still have many obstacles in reasoning. It should be remembered that one of the keys to teaching mathematical reasoning is the type of task involved in learning [34][35]. Multi-meaning vocabulary can be a barrier in learning if it is not well anticipated.

Other findings from this research that the task of interpretation of graph, in addition to the graphical representation tasks, can be a bridge towards the awareness of higher level covariational reasoning on the subject of field-dependent and field-independent. Once the subjects interpret a graph with smooth curves and concave, each subject took the initiative to take a look at their previous thought. It then becomes the potential to increase subject's reasoning. These findings concur with those of Rodriguez [36] which indicates that discussions on graph interpretation can encourage students to think productively to scaffold on mathematical reasoning. An understanding of the mathematical representation and interpretation is inseparable 
from the study of mathematics [37], so educators need to provide a meaningful experience to the students.

\section{CONCLUSIONS AND SUGGESTIONS}

The results of the covariation test do not show consistent differences regarding the level of covariational reasoning between field-independent and field-dependent subjects although there is a tendency for higher level of reasoning on field independent subjects. Field-dependent and field-independent subjects have different tendencies regarding how to respond to the context of the problem. One thing that can be identified as a determinant of different levels of reasoning is the subject's way to lock in the information needed from the context of the covariation problem presented and the subject's ability to describe problems with high complexity, which in this case is superior to individual independent fields. The level of reasoning of all subjects has the potential to increase and the task of graph interpretation has the potential to encourage improvement. Regarding the context of the problem of covariation, there is more misinterpretation in the context of the problem of time vs position or distance than the context of the problem of water volume. Differences in perception of the variable "time" inhibit the subject in completing the task so that the resulting graph cannot show the true reasoning ability of the subject. This study only covers four subjects because of the limited participants available so there is a need for further research by comparing subjects with various characters. Research comparing the effectiveness of different types of covariation tasks in learning is also a potential for further research.

\section{REFERENCES}

[1] D. Tall, "Functions and Calculus," in International Handbook of Mathematics Education, A. J. Bishop, M. K. Clements, C. Clements, K., Keitel, J. Kilpatrick, and C. Laborde, Eds. Springer, 1996, pp. 289-325.

[2] M. P. Carlson, M. Oehrtman, and N. Engelke, "The Precalculus Concept Assessment : A Tool for Assessing Students' Reasoning Abilities and Understandings," Cognition and Instruction, vol. 28, no. 2, pp. 113-145, 2010, DOI: https://doi.org/10.1080/07370001003676587.

[3] M. P. Carlson and M. Tallman, "Conceptual Precalculus: Strengthening Students' Quantitative and Covariational Reasoning," Journal of Mathematics Teacher Education, vol. 109, no. 1, pp. 54-61, 2015.

[4] M. P. Carlson, B. Madison, and R. D. West, "A Study of Students ' Readiness to Learn Calculus," International Journal of Research in Undergraduate Mathematics Education, vol. 1, no. 2, pp. 209-233, 2015, DOI: https://doi.org/10.1007/s40753-015-0013-y.

[5] E. Weber and P. W. Thompson, "Students' Images of Two-Variable Functions and Their Graphs," Educational Studies in Mathematics, 2014, DOI: https://doi.org/10.1007/s10649014-9548-0.

[6] C. Nagle et al., "The Notion of Motion: Covariational Reasoning and the Limit Concept," International Journal of Mathematical Education in Science and Technology, vol. 48, no. 4, pp. 573586, 2016, DOI: https://doi.org/10.1080/0020739X.2016.1262469. 
[7] M. P. Carlson, S. Jacobs, E. Coe, S. Larsen, and E. Hsu, "Applying Covariational Reasoning While Modeling Dynamic Events: A Framework and A Study," Journal for Research in Mathematics Education, vol. 33, no. 5, pp. 352-378, 2002.

[8] Subanji, Teori Berpikir Pseudo Penalaran Kovariasi. Malang: UM Press, 2011.

[9] P. W. Thompson and M. P. Carlson, "Variation, Covariation, and Functions: Foundational Ways of Thinking Mathematically," in Compendium for Research in Mathematics Education, J. Cai, Ed. Reston, VA: Compendium for Research in Mathematics Education, 2017, pp. 421-456.

[10] C. Castillo-Garsow, Teaching the Verbulst Model: A Teaching Experiment in Covariational Reasoning and Exponential Growth, Arizona State University, 2010.

[11] C. Castillo-Garsow, H. L. Johnson, and K. C. Moore, "Chunky and Smooth Images of Change," For the Learning of Mathematics, vol. 33, no. 3, pp. 31-37, 2013.

[12] J. E. Ormrod, Educational Psychology: Developing Learners. Pearson, 2008.

[13] R. L. Solso, O. H. Maclin, and M. K. Maclin, Cognitive Psychology, 8th ed. Pearson Education, 2008.

[14] H. A. Witkin, C. A. Moore, D. R. Goodenough, and Patricia W. Cox., "Field-Dependent and Field-Independent Cognitive Styles and Their Educational Implications," Review of Educational Research, vol. 47, no. 1, pp. 1-64, 1977.

[15] J. Snowman, R. McCown, and R. Biehler, Social Cognitive Theory, 13th ed. Belmont, CA: Wadsworth, Cengage Learning, 2012.

[16] L.-F. Zhang and R. J. Sternberg, Perspectives on the Nature of Intellectual Styles. New York: Springer, 2009.

[17] K. C. Moore and S. A. Bowling, "The Development of Covariational Thinking in a College Algebra," in Proceedings for the Eleventh Special Interest Group of Mathematical Assosiation of America on Research in Undergraduate Mathematics Education, 2008.

[18] K. C. Moore, T. Paoletti, and S. Musgrave, "Covariational Reasoning and Invariance among Coordinate Systems," Journal of Mathematical Behavior, vol. 32, no. 3, pp. 461-473, 2013, DOI: https://doi.org/10.1016/j.jmathb.2013.05.002.

[19] H. L. Johnson, “Together yet Separate: Students' Associating Amounts of Change in Quantities Involved in Rate of Change," Educational Studies in Mathematics, vol. 89, no. 1, pp. 89-110, 2015, DOI: https://doi.org/10.1007/s10649-014-9590-y.

[20] B. Liang, I. E. Stevens, H. Tasova, and K. C. Moore, "Magnitude Reasoning: Characterizing A Pre-calculus Student's Quantitative Comparison Between Covarying Magnitudes," in Proceedings of the 40th annual meeting of the North American Chapter of the International Group for the Psychology of Mathematics Education, 2018, pp. 608-611.

[21] K. Oberauer, H.-M. Süß, O. Wilhelm, and N. Sander, "Individual Differences in Working Memory Capacity and Reasoning Ability," in Variation in Working Memory, 2007, pp. 49-75.

[22] K. Oberauer, "Design for a Working Memory," Psychology of Learning and Motivation, vol. 51, pp. 45-100, 2009, DOI: https://doi.org/10.1016/S0079-7421(09)51002-X.

[23] J. Carden and T. Cline, "Problem Solving in Mathematics: the Significance of Visualisation and Related Working Memory," Educational Psychology in Practice, vol. 31, no. 3, pp. 235-246, 2015, DOI: https://doi.org/10.1080/02667363.2015.1051660.

[24] F. A. Fahrudin, "Identifikasi Kesalahan Mahasiswa dalam Menyelesaikan Soal Kalkulus Peubah Banyak Berdasarkan Taksonomi Solo," Jurnal Pendidikan Matematika Indonesia, vol. 3, no. 1, pp. 7-14, 2018. 
[25] H. Nufus and R. Ariawan, "Profil Kesalahan Mahasiswa Dalam Menyelesaikan Soal Pada Mata Kuliah Kalkulus Diferensial Berdasarkan Gaya Kognitif dan Habits Of Mind," Suska Journal of Mathematics Education, vol. 4, no. 2, pp. 108-114, 2018.

[26] A. Mujib, "Identifikasi Miskonsepsi Mahasiswa Menggunakan Ciri Pada Mata Kuliah Kalkulus II," Jurnal Musharafa, vol. 6, no. 2, pp. 181-192, 2017.

[27] D. Apriandi and I. Krisdiana, "Analisis Kesulitan Mahasiswa Dalam Memahami Materi Intgral Lipat Dua Pada Koordinat Polar Mata Kuliah Kalkulus Lanjut,” Al-Jabar: Jurnal Pendidikan Matematika, vol. 7, no. 2, pp. 123-134, 2016.

[28] P. Cho and C. Nagle, "Procedural and Conceptual Difficulties with Slope: an Analysis of Students' Mistakes on Routine Tasks," International Journal of Research in Educationand Science (IJRES), vol. 3, no. 1, pp. 135-150, 2017.

[29] N. V Harini, Y. Fuad, and R. Ekawati, "Students' Covariational Reasoning in Solving Integrals’ Problems," Journal of Physics: Conference Series, vol. 947, pp. 1-7, 2018.

[30] E. Oh and D. Lim, "Cross Relationships Between Cognitive Styles And Learner Variables in Online Learning Environment," Journal of Interactive Online Learning, vol. 4, no. 1, pp. 5366, 2005.

[31] O. Koklu, An Investigation of College Students' Covariational Reasonings, The Florida State University, 2007.

[32] S. Monk, "Students' Understanding of a Function Given by a Physical Model," In The Concept Of Function: Aspects of Epistemology and Pedagogy, 1992, pp. 175-193.

[33] D. Tall, "From Biological Brain to Mathematical Mind: The Long-term Evolution of Mathematical Thinking," in Interdisciplinary Approaches to Mathematical Cognition, 2019.

[34] M. S. Anwar, C. Choirudin, E. F. Ningsih, T. Dewi, and A. Maseleno, "Developing an Interactive Mathematics Multimedia Learning Based on Ispring Presenter in Increasing Students' Interest in Learning Mathematics," Al-Jabar: Jurnal Pendidikan Matematika, vol. 10, no. 1, pp. 135-150, Jul. 2019, DOI: https://doi.org/10.24042/ajpm.v10i1.4445.

[35] K. Brodie, Teaching Mathematical Reasoning In Scondary School Classrooms. New York: Springer, 2010.

[36] J. G. Rodriguez, K. Bain, and M. H. Towns, "Covariational Reasoning and Mathematical Narratives: Investigating Students' Understanding of Graphs in Chemical Kinetics," Chemistry Education Research and Practice, vol. 20, no. 1, pp. 107-119, 2019, DOI: https://doi.org/10.1039/c8rp00156a.

[37] NCTM, Principles and Standards for School Mathematics. Reston V.A: NCTM, 2002. 
Numerical: Jurnal Matematika dan Pendidikan Matematika, 4(1), Juni 2020, 41-54

Ulumul Umah 